\title{
FAKTOR RISIKO KEGEMUKAN PADA WANITA DEWASA INDONESIA
}

\author{
(Risk Factors of Overweight among Indonesian Women)
}

\author{
Rian Diana ${ }^{1 *}$, Indah Yuliana1, Ghaida Yasmin¹, dan Hardinsyah¹ \\ 'Departemen Gizi Masyarakat, Fakultas Ekologi Manusia (FEMA), Institut Pertanian Bogor, Bogor 16680
}

\begin{abstract}
This study was aimed to analyze risk factors of overweight women aged 19-55 years in Indonesia. This study used electronic files data of the National Basic Health Research 2010 from Ministry of Health, which was designed as a cross sectional survey. A total of 57,167 women aged 19-55 years were selected for the analysis. A logistic regression was applied to analyze risk factors of overweight. The result showed that $29.4 \%$ of subjects were overweight (including obese). The significant risk factors $(p<0.05)$ of overweight among subjects were marital status (OR for married=2.712; 95\% Cl:2.559-2.875), household income (OR for high income=1.566; 95\% Cl:1.504-1.631), living settlement (OR for urban=1.358; 95\% Cl:1.304-1.413), physical activity (OR for sedentary $=1.213$; $95 \% \mathrm{Cl}: 1.153-1.275)$, energy from carbohydrate (EAC) (OR for $E A C \geq 55 \%=1.119 ; 95 \% \mathrm{Cl}: 1.067-1.173)$, and energy from sugary sweetened foods (ESF) $(O R$ for $E S F \geq 10 \%=1.100$; $95 \% \mathrm{Cl}: 1.037-1.166)$. Education level (OR for higher education $=0.817 ; 95 \% \mathrm{Cl}: 0.782-0.853$ ) was a protective factors for overweight. This implies the importance of promoting physical activity and healthy diet, especially with sugary sweetened foods and adequate energy from carbohydrate, for preventing and controlling overweight among Indonesian adults especially women.
\end{abstract}

Keywords: overweight, risk factors, sugary foods, women

\begin{abstract}
ABSTRAK
Penelitian ini bertujuan untuk menganalisis faktor risiko kegemukan pada perempuan usia 19-55 tahun di Indonesia. Analisis ini menggunakan data elektronik dari Riset Kesehatan Dasar (Riskesdas) tahun 2010, Balitbangkes, Kementerian Kesehatan dengan desain cross-sectional. Total subjek sebanyak 57167 perempuan usia 19-55 tahun. Regresi logistik digunakan untuk menganalisis faktor risiko kegemukan. Hasil analisis menunjukkan bahwa sebanyak $29.4 \%$ subjek mengalami kegemukan (termasuk obes). Faktor risiko $(p<0.05)$ kegemukan pada subjek yaitu status perkawinan (OR untuk kawin=2.712; $95 \% \mathrm{Cl}: 2.559-2.875$ ), pendapatan rumah tangga (OR untuk pendapatan menengah ke atas=1.566; 95\% $\mathrm{Cl}: 1.504-1.631$ ), tipe wilayah (OR untuk perkotaan=1.358; 95\% Cl:1.304-1.413), aktivitas fisik (OR untuk aktivitas ringan=1.213; 95\% Cl:1.153-1.275), energi dari karbohidrat (EKA) (OR untuk $E K A \geq 55 \%=1.119 ; 95 \% \mathrm{Cl}: 1.067-1.173$ ), serta energi dari makanan dan minuman manis $(E M M)(O R$ untuk $E M M \geq 10 \%=1.100 ; 95 \% \mathrm{Cl}: 1.037-1.166)$. Tingkat pendidikan (OR untuk pendidikan lebih tinggi=0.817; $95 \% \mathrm{Cl}: 0.782-0.853$ ) merupakan faktor protektif kegemukan. Penelitian ini berimplikasi pada pentingnya mempromosikan aktivitas fisik dan diet yang sehat terutama menurunkan konsumsi makanan dan minuman manis dan konsumsi karbohidrat yang tidak berlebih untuk pencegahan dan pengendalian kegemukan.
\end{abstract}

Kata kunci: faktor risiko, kegemukan, makanan manis, perempuan

"Korespondensi: Departemen Gizi Masyarakat, Fakultas Ekologi Manusia (FEMA), Institut Pertanian Bogor, Bogor 16680. Email: rian.diana@yahoo.com 


\section{PENDAHULUAN}

Pencapaian Indeks Pembangunan Manusia di dunia tidak terlepas dari segi peningkatan kualitas kesehatan. Namun, saat ini masih banyak masalah gizi yang dapat memengaruhi kualitas kesehatan salah satunya adalah masalah kegemukan. Pencegahan epidemi kegemukan merupakan salah satu tantangan besar gizi dan kesehatan masyarakat baik di negara maju maupun negara berkembang. Prevalensi kegemukan cenderung meningkat seiring dengan peningkatan usia, dan mencapai puncaknya pada usia dewasa. Terdapat kecenderungan prevalensi kegemukan yang meningkat seiring dengan peningkatan usia, dan mencapai puncaknya pada usia dewasa. Hasil Riskesdas 2010 menunjukkan bahwa $21.7 \%$ orang dewasa Indonesia mengalami kegemukan (termasuk obesitas), dan perempuan memiliki prevalensi yang lebih tinggi (26.9\%) dibandingkan laki-laki (16.3\%) (Balitbangkes 2010).

Kegemukan dapat meningkatkan risiko penyakit tidak menular seperti diabetes sebanyak 4.5 kali, hipertensi 2.5 kali, dan penyakit jantung koroner sebesar 32\% (Mendez et al. 2004; Bogers et al. 2007). Peningkatan risiko ini dapat meningkatkan perawatan kesehatan, kunjungan dokter, hilangnya hari kerja, dan kematian selain itu juga menurunkan kualitas hidup (Cawley \& Meyerhoefer 2012; Swinburn et al. 2004).

WHO telah menghimbau semua negara untuk mengatasi dan mencegah masalah kegemukan yang didasarkan pada pengendalian faktor risiko kegemukan di masing-masing negara. Sehubungan hal ini, diperlukan kajian tentang faktor risiko kegemukan untuk mengendalikannya. Penelitian mengenai faktor risiko kegemukan telah banyak dilakukan di manca negara (Brown \& Siahpush 2007; Phillips et al. 2012; Shayo \& Mugusi 2011), sementara di Indonesia hanya dalam skala kecil di kota Depok (Nurzakiah et al. 2010) dan tidak khusus pada perempuan (Roemling \& Qaim 2012; Sartika 2011). Pada tahun 2010, Badan Penelitian dan Pengembangan Kesehatan telah melakukan penelitian data dasar kesehatan skala nasional dan data tersebut berpotensi untuk diolah dan digunakan. Penelitian ini bertujuan untuk menganalisis faktor risiko kegemukan terkait sosial ekonomi, konsumsi pangan dan zat gizi pada perempuan dewasa usia 19-55 tahun di Indonesia.

\section{METODE}

\section{Desain, Tempat, dan Waktu}

Desain yang digunakan dalam penelitian ini adalah cross-sectional. Subjek mewakili 33 provinsi yang tersebar di 441 kabupaten/kota diseluruh provinsi di Indonesia. Pengolahan dan analisis lanjut data dilakukan pada bulan April-Mei 2013 di Kampus IPB Darmaga Bogor, Jawa Barat.

\section{Jumlah dan Cara Penarikan Subjek}

Subjek rumah tangga dalam Riskesdas 2010 dipilih berdasarkan listing Sensus Penduduk (SP) 2010. Proses pemilihan rumah tangga dilakukan BPS dengan two stages sampling. Subjek penelitian ini adalah perempuan usia 19-55 tahun. Data yang digunakan adalah data antropometri, konsumsi pangan dan sosial ekonomi. Kriteria inklusi subjek pada analisis ini yaitu berusia 19-55 tahun, tidak hamil, dan memiliki data lengkap. Kriteria eksklusi yaitu hamil, berat badan (BB), tinggi badan (TB), dan indeks massa tubuh (IMT) yang bernilai kurang dari rata-rata-4SD dan lebih dari rata-rata+4SD, tingkat kecukupan energi (TKE) $(40 \%<$ TKE $<300 \%)$, sedang diet, puasa atau hari merayakan pesta. Total subjek orang dewasa usia 19-55 tahun adalah 132736. Subjek perempuan dewasa usia 19-55 tahun berjumlah 68 486. Setelah proses cleaning, data jumlah subjek akhir adalah 57167 subjek.

\section{Jenis dan Cara Pengumpulan Data}

Penelitian ini menggunakan data sekunder (electronic files) Riskesdas 2010 yang dilakukan oleh Balitbangkes, Kementerian Kesehatan. Data yang digunakan meliputi variabel karakteristik sosial ekonomi dan demografi (status perkawinan, tingkat pendidikan, pendapatan rumah tangga, dan tipe wilayah), aktivitas fisik (jenis pekerjaan), konsumsi pangan (konsumsi makanan dan minuman manis serta sayur dan buah), asupan energi dan zat gizi (asupan energi, protein, lemak, karbohidrat, dan serat) serta data berat badan dan tinggi badan.

Pengumpulan data dilakukan oleh Tim Riskesdas dari Balitbangkes, Kementerian Kesehatan yang dilakukan pada bulan Mei-Agustus 2010. Data karakteristik sosial ekonomi dan demografi diperoleh dengan cara wawancara langsung kepada subjek menggunakan kuesioner terstruktur yang dilengkapi buku pedoman pengisian kuesioner. Data konsumsi pangan diperoleh dengan metode kuantitatif recall 24 jam. Pengukuran berat badan dilakukan dengan timbangan berat badan digital merek "AND" (kg). Tinggi badan menggunakan alat ukur tinggi badan "Multifungsi" dengan kapasitas ukur dua meter dan ketelitian $0.1 \mathrm{~cm}$. Hasil pengukuran dihitung ke dalam nilai IMT $\left(\mathrm{kg} / \mathrm{m}^{2}\right)$.

\section{Pengolahan dan Analisis Data}

Kategori data penelitian terdiri dari variabel dependen (kejadian kegemukan) dan variabel independen (karakteristik sosial ekonomi, karakteristik 
demografi, aktivitas fisik, konsumsi pangan, serta asupan energi, dan zat gizi). Aktivitas fisik berhubungan dengan gaya hidup populasi, yaitu hal-hal yang berhubungan dengan jenis pekerjaan seharihari (FAO 2001). Berdasarkan pernyataan tersebut, aktivitas fisik dikategorikan melalui pendekatan jenis pekerjaan, yaitu aktivitas berat (petani, nelayan, buruh) dan aktivitas ringan (tidak bekerja/ sekolah, ibu rumah tangga, TNI/Polri, pegawai BUMN, wiraswasta/pedagang/jasa, dan lainnya). Variabel konsumsi pangan yang dianalisis yaitu makanan dan minuman manis (makanan dan minuman yang secara alami mengandung atau ditambah gula sederhana) serta sayur dan buah (semua jenis sayur dan buah baik segar maupun olahan). Pengkategorian konsumsi pangan serta asupan zat gizi mengacu pada WHO (2003). IMT tergolong kurus/normal jika $<25 \mathrm{~kg} / \mathrm{m}^{2}$ dan gemuk/obes jika $\geq 25 \mathrm{~kg} / \mathrm{m}^{2}$ (WHO 2003).

Analisis deskriptif menggambarkan distribusi frekuensi baik jumlah maupun persentase. Uji Chi-square digunakan untuk mengetahui hubungan variabel dependen dengan salah satu independen. Untuk mengetahui nilai faktor risiko atau Odds Ratio (OR) variabel independen terhadap variabel dependen digunakan model binary logistic regression dengan metode backward wald (Agresti \& Finlay 2009). Model yang digunakan adalah sebagai berikut:

$$
Y=\log \frac{F}{1-F}=\begin{aligned}
& \beta_{0}+\beta_{1} X_{1}+\beta_{2} X_{2}+\beta_{3} X_{3}+\beta_{4} X_{4}+\beta_{5} X_{5}+\beta_{6} X_{6}+\beta_{7} X_{7} \\
& +\beta_{8} X_{8}+\beta_{9} X_{9}+\beta_{10} X_{10}+\beta_{11} X_{11}+\beta_{12} X_{12}+\varepsilon
\end{aligned}
$$

Keterangan:

$F=$ fungsi kumulatif; $B_{0}=$ intercept; $B_{1}-B_{12}=$ koefisien regresi; $\mathrm{x}_{1}=$ status perkawinan [0=tidak kawin, $1=$ lainnya]; $\mathrm{x}_{2}=$ tipe wilayah [0=pedesaan, $1=$ perkotaan]; $x_{3}=$ tingkat pendidikan [0=tidak sekolah sampai tamat SMP, 1=lainnya]; $\mathrm{x}_{4}=$ kuintil pendapatan rumah tangga [0=kuintil, 1 sampai $2 / 40 \%$ terbawah, 1=lainnya]; $x_{5}$ =aktivitas fisik [0=berat/petani, nelayan dan buruh, 1=ringan/lainnya]; $\mathrm{x}_{6}=$ konsumsi makanan dan minuman manis [0=cukup, $1=$ lebih/>10\% AKE]; $x_{7}=$ konsumsi sayur dan buah [0=cukup, $1=$ kurang/<400 g/hari]; $x_{8}=$ tingkat kecukupan energi [0=kurang/cukup, $1=$ lebih/ $\geq 110 \%$ AKE]; $x_{9}=$ asupan karbohidrat [0=cukup, $1=$ lebih/>55\% AKE]; $x_{10}=$ asupan protein [0=cukup, $1=$ lebih $/>15 \%$ AKE]; $x_{11}=$ asupan lemak [0=cukup, $1=$ lebih/>25\% AKE]; $x_{12}=$ asupan serat [0=cukup, $1=$ kurang $/<25$ g serat/hari]; $\varepsilon=$ galat

\section{HASIL DAN PEMBAHASAN}

Berdasarkan hasil analisis, prevalensi kegemukan (termasuk obes) pada perempuan dewasa usia $19-55$ tahun sebesar $29.4 \%$. Nilai tersebut sedikit lebih tinggi dari prevalensi nasional kegemukan (termasuk obes) pada perempuan dewasa usia $>18$ tahun yaitu sebesar 26.9\% (Balitbangkes 2010). Sebagian besar subjek telah menikah, berpendidikan SMP ke bawah, memiliki pendapatan rumah tangga menengah ke atas, dan tinggal di perkotaan. Sebagian besar subjek juga bergaya hidup sedentary atau memiliki aktivitas fisik ringan.

\section{Karakteristik Sosial Ekonomi dan Demografi}

Analisis Chi-square karakteristik sosial ekonomi dan demografi dengan status gizi menunjukkan bahwa prevalensi kegemukan ditemukan lebih tinggi dan signifikan pada subjek yang sudah menikah, berpendidikan SMP ke bawah, memiliki pendapatan rumah tangga menengah ke atas dan tinggal di perkotaan $(p<0.05)$ (Tabel 1$)$. Hasil yang sama juga ditunjukkan oleh Shayo dan Mugusi (2011), serta Roemling dan Qaim (2012). Analisis regresi logistik menunjukkan bahwa semua variabel karakteristik

\begin{tabular}{|c|c|c|c|c|c|c|}
\hline & & \multicolumn{4}{|c|}{ Status Gizi } & \multirow{3}{*}{$\mathrm{p}$} \\
\hline \multirow{2}{*}{\multicolumn{2}{|c|}{ Variabel }} & \multicolumn{2}{|c|}{$\begin{array}{l}\text { Normal/kurus } \\
(n=40376)\end{array}$} & \multicolumn{2}{|c|}{$\begin{array}{c}\text { Gemuk/obes } \\
(n=16791)\end{array}$} & \\
\hline & & $n$ & $\%$ & $\mathrm{n}$ & $\%$ & \\
\hline \multirow[t]{2}{*}{ Status perkawinan: } & Tidak kawin & 8633 & 84.4 & 1590 & 15.6 & \multirow{2}{*}{$0.000^{*}$} \\
\hline & Kawin & 31743 & 67.6 & 15201 & 32.4 & \\
\hline \multirow[t]{2}{*}{ Tingkat pendidikan: } & Pendidikan dasar & 26752 & 70.2 & 11345 & 29.8 & \multirow{2}{*}{$0.003^{*}$} \\
\hline & Pendidikan tinggi & 13624 & 71.4 & 5446 & 28.6 & \\
\hline \multirow[t]{2}{*}{ Pendapatan rumah tangga: } & Pendapatan rendah & 17482 & 76.2 & 5454 & 23.8 & \multirow{2}{*}{$0.000^{*}$} \\
\hline & Pendapatan tinggi & 22894 & 66.9 & 11337 & 33.1 & \\
\hline \multirow[t]{2}{*}{ Tipe wilayah: } & Pedesaan & 19795 & 74.1 & 6971 & 25.9 & \multirow{2}{*}{$0.000^{*}$} \\
\hline & Perkotaan & 20581 & 67.6 & 9874 & 32.4 & \\
\hline \multirow[t]{2}{*}{ Aktivitas fisik: } & Berat & 8698 & 75.3 & 2860 & 24.7 & \multirow{2}{*}{$0.000^{*}$} \\
\hline & Ringan & 31678 & 69.5 & 13931 & 30.5 & \\
\hline
\end{tabular}

Tabel 1. Hubungan Karakteristik Sosial Ekonomi dan Demografi serta Aktivitas Fisik dengan Status Gizi 
Tabel 2. Faktor Risiko Kegemukan Wanita Dewasa Usia 19-55 tahun di Indonesia

\begin{tabular}{|c|c|c|}
\hline Variabel & B & OR $(95 \% \mathrm{Cl})$ \\
\hline Status kawin (1=kawin, $0=$ tidak kawin) & 0.998 & $2.712(2.559-2.875)^{*}$ \\
\hline Tingkat pendidikan $(1=\geq S M A, 0=$ lainnya $)$ & -0.202 & $0.817(0.782-0.853)^{*}$ \\
\hline Pendapatan rumah tangga ( $1=$ =menengah-atas, $0=$ =lainnya) & 0.449 & $1.566(1.504-1.631)^{*}$ \\
\hline Tipe wilayah ( $1=$ perkotaan, $0=$ pedesaan $)$ & 0.306 & $1.358(1.304-1.413)^{*}$ \\
\hline Aktivitas fisik ( $1=$ ringan, $0=$ berat) & 0.193 & $1.213(1.153-1.275)^{*}$ \\
\hline Kons. makanan dan minuman manis $(1=>10 \%$ AKE, $0=\leq 10 \%$ AKE) & 0.095 & $1.100(1.037-1.166)^{*}$ \\
\hline Asupan karbohidrat $(1=>55 \%$ AKE, $0=\leq 55 \%$ AKE $)$ & 0.112 & $1.119(1.067-1.173)^{*}$ \\
\hline
\end{tabular}

Keterangan: *signifikan pada $a<5 \%$

sosial ekonomi dan demografi berpengaruh signifikan terhadap kejadian kegemukan (Tabel 2).

Analisis regresi logistik menunjukkan bahwa perempuan yang sudah menikah berisiko hampir 3 kali lebih tinggi untuk mengalami kegemukan dibandingkan perempuan yang belum/tidak menikah (OR=2.712; 95\% Cl:2.559-2.875) (Tabel 2). Status perkawinan merupakan prediktor kuat kejadian kegemukan dan adipositas sentral pada perempuan. Perempuan yang sudah menikah cenderung kurang peduli jika bertambah berat badan atau menjadi gemuk, berbeda halnya ketika sebelum menikah, perempuan menjaga berat badannya agar lebih mudah mendapatkan pasangan. Selain itu, peningkatan berat badan pada saat hamil meningkatkan cadangan lemak. Semakin banyak cadangan lemak maka semakin lama penurunan berat badan terjadi. Setelah melahirkan, $75 \%$ perempuan memiliki ratarata BB 6 kg lebih tinggi (Bove \& Sobal 2011; Dahly et al. 2010; Walker et al. 2004).

Hasil analisis ini menunjukkan bahwa tingkat pendidikan merupakan faktor protektif terhadap kegemukan karena subjek yang berpendidikan SMA ke atas berisiko $20 \%$ lebih rendah mengalami kegemukan dibandingkan subjek yang berpendidikan SMP ke bawah (Tabel 2). Hasil ini sejalan dengan penelitian Cohen et al. (2013) yang menunjukkan bahwa lulusan perguruan tinggi risikonya lebih rendah untuk mengalami obesitas dibandingkan lulusan sekolah dasar $(R R=0.96)$. Seseorang dengan tingkat pendidikan yang lebih tinggi akan lebih baik dalam menerima, memproses, menginterpretasikan, dan menggunakan informasi, khususnya pengetahuan gizi (Contento 2007). Subjek yang berpendidikan lebih tinggi akan memiliki pengetahuan gizi yang lebih tinggi karena memiliki pengalaman dan akses informasi yang lebih banyak sehingga dapat memiliki sikap dan praktik gizi yang lebih baik khususnya dalam hal perilaku konsumsi pangan dan aktivitas fisik yang erat kaitannya dengan kegemukan.

Subjek yang berpendapatan menengah ke atas berisiko 1.566 kali lebih besar mengalami kegemukan dibandingkan subjek berpendapatan menengah ke bawah (Tabel 2). Subjek berstatus gizi gemuk menggunakan pendapatannya lebih banyak untuk pengeluaran pangan khususnya daging dan olahan susu, tetapi lebih sedikit pengeluaran pangan untuk pangan tradisional (Roemling \& Qaim 2012). Wilayah tempat tinggal juga menjadi faktor risiko kegemukan dimana subjek yang tinggal di perkotaan berisiko 1.358 kali lebih besar mengalami kegemukan (Tabel 2). Lingkungan perkotaan seperti akses pangan dan sarana transportasi diduga mendukung gaya hidup yang mengarah pada kegemukan seperti mudahnya akses pangan siap saji dan sarana transportasi yang dapat mengurangi tingkat aktivitas fisik.

\section{Aktivitas Fisik}

Analisis Chi-square menunjukkan bahwa aktivitas fisik berhubungan negatif dengan status gizi gemuk. Subjek yang beraktivitas fisik ringan berisiko lebih tinggi mengalami kegemukan dibandingkan subjek yang beraktivitas fisik berat $(O R=1.213$; 95\% Cl:1.153-1.275)). Hal tersebut juga sesuai dengan hasil penelitian Brock et al.(2009), Banks et al. (2011), Shayo dan Mugusi (2011), serta Roemling dan Qaim (2012).

Subjek pada analisis ini merupakan perempuan yang sebagian besar sudah menikah dan menjadi ibu rumah tangga. Ibu rumah tangga tergolong dalam pekerjaan dengan aktivitas fisik ringan. Pada analisis ini, aktivitas fisik didekati dari jenis pekerjaan. Jenis pekerjaan yang tergolong aktivitas fisik ringan tersebut merupakan jenis pekerjaan yang tidak membutuhkan banyak usaha fisik, tidak perlu untuk berjalan kaki jarak jauh, umumnya menggunakan kendaraan bermotor untuk transportasi, dan menghabiskan sebagian besar waktunya dengan duduk atau sedikit gerakan badan (membaca atau menggunakan komputer) (FAO 2001).

Pengurangan berat badan 3-5\% secara nyata dapat menurunkan risiko kesehatan. American College of Sports Medicine merekomendasikan melakukan aktivitas sedang sampai berat minimal 250 menit/ minggu bagi orang yang ingin menurunkan lemak tubuh (Durstine et al. 2013). WHO (2010) 
merekomendasikan orang dewasa usia 18-64 tahun beraktivitas fisik aerobik dengan intensitas sedang minimum 150 menit per minggu atau beraktivitas fisik aerobik dengan intensitas berat minimum 75 menit per minggu untuk meningkatkan kesehatan kardiorespiratori, otot, dan tulang serta menurunkan risiko penyakit tidak menular dan depresi.

\section{Konsumsi Pangan dan Asupan Zat Gizi}

Hasil analisis Chi-square menunjukkan bahwa terdapat hubungan nyata antara konsumsi makanan dan minuman manis $(p=0.000)$, tingkat kecukupan energi $(p=0.000)$, asupan karbohidrat $(p=0.000)$, asupan protein $(p=0.000)$, dan asupan lemak $(p=0.000)$ dengan kegemukan. Prevalensi kegemukan lebih tinggi pada perempuan yang mengonsumsi makanan dan minuman manis $>10 \%$ AKE, karbohidrat $>55 \%$ AKE, protein $>15 \%$ AKE, lemak $>25 \%$ AKE serta tingkat kecukupan energinya $\geq 110 \%$ AKE (Tabel 3 ). Hal yang sama juga terjadi pada penelitian Mirmiran et al. (2006), Guallar-Castillon et al. (2007), Esmaillzadeh \& Azadbakh (2008) dan Febriyani et al. (2012). Tingginya asupan energi tanpa diikuti dengan peningkatan aktivitas fisik akan menyebabkan tubuh menyimpan energi ekstra sebagai lemak dan mengakibatkan kegemukan (Smolin \& Grosvenor 2010). Hasil penelitian kohort selama 7 tahun menunjukkan bahwa orang yang mengonsumsi pangan sumber protein hewani berisiko terkena obesitas sebesar 4.62 kali. Hal ini diduga karena pangan sumber protein hewani juga merupakan pangan yang tinggi lemak (Bujnowski et al. 2011) dan asupan lemak yang tinggi berhubungan dengan risiko kegemukan (Phi llips et al. 2012).

Berbeda halnya dengan konsumsi sayur dan buah serta asupan serat yang tidak signifikan berhubungan dengan kejadian kegemukan. Studi Vergnaud et al. (2012) juga menyimpulkan hal yang sama. Hasil penelitian ini tidak sejalan dengan penelitian Liu et al. (2003) dan Buijsse et al. (2009) yang menunjukkan bahwa terdapat hubungan berbanding terbalik antara peningkatan berat badan wanita dengan peningkatan asupan sayur dan buah, asupan tinggi serat dan makanan gandum (whole grain). Perbedaan hasil penelitian ini, dapat terjadi karena sedikitnya jumlah subjek yang mengonsumsi serat, sayur, dan buah dalam jumlah yang cukup, sehingga tidak dapat menggambarkan hubungan antara makanan tersebut dengan kegemukan.

Setelah dilakukan uji regresi logistik, hanya konsumsi makanan dan minuman manis serta asupan karbohidrat yang berisiko meningkatkan kegemukan (Tabel 3). Risiko kegemukan meningkat 1.100 kali lebih besar pada perempuan yang mengonsumsi makanan dan minuman manis $>10 \%$ AKE $(95 \% \mathrm{Cl}$ : 1.037-1.166). Banyak bukti epidemiologi dan eksperimental yang menunjukkan bahwa konsumsi makanan dan minuman manis berhubungan dengan pertambahan berat badan dan kegemukan. Konsumsi minuman manis terutama minuman ringan berkarbonasi mungkin menjadi faktor risiko pada epidemi kegemukan melalui kandungan gula yang tinggi, rasa kenyang rendah dan kontribusinya terhadap total energi (Malik et al. 2006). Tingginya

Tabel 3. Hubungan Konsumsi Pangan serta Tingkat Kecukupan Energi dan Asupan Zat Gizi dengan Status Gizi

\begin{tabular}{|c|c|c|c|c|c|c|}
\hline \multirow{3}{*}{ Variabel } & & \multicolumn{4}{|c|}{ Status Gizi } & \multirow{3}{*}{$\mathrm{p}$} \\
\hline & & \multicolumn{2}{|c|}{$\begin{array}{c}\text { Normal/kurus } \\
(\mathrm{n}=40376)\end{array}$} & \multicolumn{2}{|c|}{$\begin{array}{c}\text { Gemuk/obes } \\
(n=16 \text { 791) }\end{array}$} & \\
\hline & & $\mathrm{n}$ & $\%$ & $\mathrm{n}$ & $\%$ & \\
\hline \multirow[t]{2}{*}{ Kons. makanan dan minuman manis: } & Cukup ( $\leq 10 \%$ AKE) & 36083 & 71.1 & 14683 & 28.9 & \multirow{2}{*}{$0.000^{*}$} \\
\hline & Lebih (>10\% AKE) & 4293 & 67.1 & 2108 & 32.9 & \\
\hline \multirow[t]{2}{*}{ Kons. sayur dan buah: } & Cukup ( $\geq 400 \mathrm{~g} / \mathrm{hr})$ & 2242 & 69.4 & 988 & 30.6 & \multirow{2}{*}{0.118} \\
\hline & Kurang (<400 g/hr) & 38134 & 70.7 & 15803 & 29.3 & \\
\hline \multirow[t]{2}{*}{ Tk. kecukupan energi: } & Kurang/cukup (<110\% AKE) & 36083 & 71.1 & 14653 & 28.9 & \multirow{2}{*}{$0.000^{*}$} \\
\hline & Lebih ( $\geq 110 \%$ AKE) & 4293 & 66.8 & 2138 & 33.2 & \\
\hline \multirow[t]{2}{*}{ Asupan karbohidrat: } & Cukup ( $\leq 55 \%$ AKE) & 33353 & 71.2 & 13476 & 28.8 & \multirow{2}{*}{$0.000^{*}$} \\
\hline & Lebih (>55\% AKE) & 7023 & 67.9 & 3315 & 32.1 & \\
\hline \multirow[t]{2}{*}{ Asupan protein: } & Cukup ( $\leq 15 \%$ AKE) & 34810 & 71.0 & 14208 & 29.0 & \multirow{2}{*}{$0.000^{*}$} \\
\hline & Lebih (>15\% AKE) & 5566 & 68.3 & 2583 & 31.7 & \\
\hline \multirow[t]{2}{*}{ Asupan lemak: } & Cukup ( $\leq 25 \%$ AKE) & 29449 & 71.3 & 11869 & 28.7 & \multirow{2}{*}{$0.000^{*}$} \\
\hline & Lebih (>25\% AKE) & 10927 & 68.9 & 4922 & 31.1 & \\
\hline \multirow[t]{2}{*}{ Asupan serat: } & Cukup ( $\geq 25 \mathrm{~g} / \mathrm{hr}$ ) & 254 & 67.4 & 123 & 32.6 & \multirow{2}{*}{0.164} \\
\hline & Kurang (<25 g/hr) & 40122 & 70.6 & 16668 & 29.4 & \\
\hline
\end{tabular}

Keterangan: *signifikan pada $\mathrm{a}<5 \%$ 
konsumsi makanan dan minuman yang mengandung densitas energi yang tinggi seperti tinggi lemak, gula dan pati akan meningkatkan asupan total energi (WHO 2003). Selain meningkatkan risiko kegemukan, konsumsi karbohidrat yang tinggi juga meningkatkan risiko metabolik sindrom pada perempuan dengan IMT $\geq 25$ (Kim et al. 2008).

Perempuan yang mengonsumsi karbohidrat $>55 \%$ AKE meningkatkan risiko kegemukan 1.119 kali lebih tinggi dibandingkan dengan perempuan yang mengonsumsi karbohidrat $\leq 55 \%$ AKE. Hasil yang sama juga ditemukan pada studi cross-sectional di Kanada menunjukkan bahwa risiko kegemukan terendah terjadi pada individu yang mengonsumsi $290-310 \mathrm{~g} /$ hari karbohidrat atau 47-64\% energi dari karbohidrat (Merchant et al. 2009).

Konsumsi sayur dan buah, serat, protein, lemak, dan tingkat kecukupan energi tidak menjadi faktor risiko kegemukan. Ketidakkonsistenan beberapa hasil penelitian ini dengan penelitian yang sudah ada dapat disebabkan oleh pengambilan data exposure dan outcome dalam waktu yang bersamaan, serta pengumpulan data konsumsi pangan yang kurang menggambarkan pola konsumsi pangan subjek.

Keterbatasan analisis ini adalah menggunakan data sekunder dimana terdapat beberapa asumsi. Adanya variabel yang tidak diukur secara langsung seperti aktivitas fisik (hanya didekati dari jenis pekerjaan). Desain cross-sectional yang mengambil data exposure dan outcome secara bersamaan sehingga belum dapat menjelaskan hubungan sebab akibat. Metode pengumpulan data konsumsi pangan dengan recall 24 jam kurang dapat menggambarkan pola konsumsi pangan subjek. Namun hasil analisis ini konsisten dengan review WHO (2003) dan WHO (2010) bahwa faktor risiko kegemukan adalah konsumsi pangan (terutama makanan tinggi densitas energi) dan aktivitas fisik. Hasil analisis ini mendukung perlunya peningkatan kesadaran hidup sehat melalui gizi seimbang dan aktivitas fisik terutama pada perempuan dewasa di Indonesia untuk pencegahan kegemukan.

\section{KESIMPULAN}

Prevalensi kegemukan pada perempuan dewasa usia $19-55$ tahun sebesar $29.4 \%$. Perempuan yang berstatus kawin, berpendapatan tinggi, tinggal di perkotaan, beraktivitas fisik ringan, mengonsumsi makanan dan minuman manis $>10 \%$ AKE, mengonsumsi karbohidrat $>55 \%$ AKE, serta berpendidikan tinggi berisiko mengalami kegemukan berturut-turut 2.712, 1.566, 1.358, 1.213, 1.100, 1.119, 0.817 kali lebih besar dibandingkan dengan kelompok pembandingnya. Tingkat kecukupan energi, asupan lemak dan protein, konsumsi sayur dan buah serta serat tidak menunjukkan hasil yang signifikan terhadap kegemukan. Perbedaan hasil penelitian ini dengan penelitian lainnya kemungkinan disebabkan oleh desain penelitian yang mengambil exposure dan outcome pada saat yang bersamaan dan penggunaan metode recall 24-hours dalam pengumpulan data konsumsi pangan. Tingkat pendidikan yang tinggi dapat menjadi faktor pencegah kegemukan, oleh karena itu pendidikan gizi seimbang dan aktivitas fisik serta promosi kesehatan perlu dilakukan pemerintah bersama stakeholder secara berkesinambungan untuk mengurangi prevalensi kegemukan dan dampak buruknya terhadap kesehatan.

\section{UCAPAN TERIMA KASIH}

Terima kasih kepada Kepala Balitbangkes, Kementerian Kesehatan RI yang telah memberikan kesempatan untuk menganalisis sebagian data Riset Kesehatan Dasar tahun 2010 untuk tulisan ini.

\section{DAFTAR PUSTAKA}

Agresti A \& Finlay B. 2009. Statistical Methods for The Social Sciences Fourth Editions. Prentice Hall Inc, New Jersey.

[Balitbangkes] Badan Penelitian dan Pengembangan Kesehatan Kementerian Kesehatan RI. 2010. Riset Kesehatan Dasar 2010. Kementerian Kesehatan Republik Indonesia, Jakarta.

Banks E, Lim L, Seubsman SA, Bain C, \& Sleigh A. 2011. Relationship of obesity to physical activity, domestic activities, and sedentary behaviours: cross-sectional findings from a national cohort of over 70,000 Thai adults. BMC Public Health, 11, 762.

Bogers RP, Bemelmans WJ, \& Hoogenveen RT et al. 2007. Association of overweight with increased risk of coronary heart disease partly independent of blood pressure and cholesterol levels: a meta-analysis of 21 cohort studies including more than 300,000 persons. Arch Intern Med. 167, 1720-8.

Bove CF \& Sobal J. 2011. Body weight relationship in early marriage: weight relevance, weight comparisons, and weight talk. Appetite, (57), 729-742.

Brock et al. 2009. Association between insufficiently physically active and the prevalence of obesity in the United States. J Phys Act Health, 6(1), 1-5.

Brown A \& Siahpush M. 2007. Risk factors for overweight and obesity: results from the 2001 national health survey. Public Health,12, 603613.

Buijsse B, Feskens EJM, Schulze MB, Forouhi NG, 
Wareham NJ, Sharp S, Palli D, Tognon G, Halkjaer J, \& Tjønneland A et al. 2009. Fruit and vegetable intakes and subsequent changes in body weight in European populations: results from the project on Diet, Obesity, and Genes (DiOGenes). Am J Clin Nutr, 90, 202-209.

Bujnowski et al. 2011. Longitudinal association between animal and vegetable protein intake and obesity among adult males in the United States: the Chicago Western Electric Study. J Am Diet Assoc, 111(8), 1150-1155.

Cawley J \& Meyerhoefer C. 2012. The medical care costs of obesity: An Instrumental variables approach. Journal of Health Economics, 31, 219-230.

Contento IR. 2007. Nutrition Education: Linking Research, Theory, and Practice. Jones and Bartlett Publishers, Sudbury.

Cohen AK, Rehkopf DH, Deardorff J, Abrams B. 2013. Education and obesity at age 40 among American adults. Social Science \& Medicine, 78, 34-41.

Dahly DL, Gordon-Larsen P, Popkin BM, Kaufman JS, \& Adair LS. 2010. Associations between multiple indicators of socioeconomic status and obesity in young adult Filipinos vary by gender, urbanicity, and indicator used. J. Nutr, 140, 366-370.

Durstine JL, Gordon B, Wang Z, \& Luo X. 2013. Chronic disease and the link to physical activity. Journal of Sport and Health Science, 2, $3-11$.

Esmaillzadeh A \& Azadbakh L. 2008. Major Dietary Patterns in Relation to General Obesity and Central Adiposity among Iranian Women. J. Nutr, 138, 358-363.

[FAO] Food and Agricultural Organization. 2001. FAO Food and Nutrition Technical Report Series: Human energy requirements Report of a Joint $\mathrm{FAO} / \mathrm{WHO} / \mathrm{UNU}$ Expert Consultation, Rome, 17-24 October 2001.

Febriyani NMPS, Hardinsyah, \& Briawan D. 2012. Minuman berkalori dan kontribusinya terhadap total asupan energi remaja dan dewasa. Jurnal Gizi dan Pangan, 7(1),35-42.

Guallar-Castillon P, Rodríguez-Artalejo F, Fornés NS, Banegas JR, Etxezarreta PA, Ardanaz E, Barricarte $A$, Chirlaque $M D$, Iraeta $M D$, \& Larrannaga NL, et al. 2007. Intake of fried foods is associated with obesity in the cohort of Spanish adults from the European Prospective Investigation into Cancer and Nutrition. Am J Clin Nutr, 86, 198-205.

Kim K, Yun SH, Choi BY, \& Kim MK. 2008. Cross-sectional relationship between dietary carbohydrate, glycaemic index, glycaemic load and risk of the metabolic syndrome in a Korean population. British Journal of Noutrition, 100, 576-584.

Liu S, Willett WC, Manson JE, Hu FB, Rosner B, \& Colditz G. 2003. Relation between changes in intakes of dietary fiber and grain products and changes in weight and development of obesity among middle-aged women. Am J Clin Nutr, 78, 920-927.

Mendez MA, Cooper RS, Luke A, Wilks R, Bennett F, \& Forrester T. 2004. Higher income is more strongly associated with obesity than with obesity-related metabolic disorders in Jamaican adults. International Journal of Obesity, 28, 543-550.

Malik VS, Schulze MB, \& HU FB. 2006. Intake of sugar-sweetened beverages and weight gain: a systematic review. Am J Clin Nutr, 84, 274288.

Merchant AT, Vatanparast H, Barlas S, Dehghan M, Shah MA, de Koning L, \& Steck SE. 2009. Carbohydrate Intake and Overweight and Obesity among Healthy Adults. J Am Diet Assoc, 109(7), 1165-1172.

Mirmiran P, Esmaillzadeh A, \& Azizi F. 2006. Diet composition and body mass index in Tehranian adults. Asia Pacific Journal of Clinical Nutrition, 15(2), 224-230.

Nurzakiah, Achadi E, \& Sartika RAD. 2010. Faktor risiko obesitas pada orang dewasa urban dan rural. Jurnal Kesehatan Masyarakat Nasional, 5(1), 29-34.

Phillips et al. 2012. High dietary saturated fat intake accentuates obesity risk associated with the fat mass and obesity-associated gene in adults. J. Nutr, 142, 824-831.

Roemling C \& Qaim M. 2012. Obesity trends and determinants in Indonesia. Appetite, 58(3), 1005-1013.

Sartika RAD. 2011. Faktor risiko obesitas pada anak 5-15 tahun di Indonesia. Makara Kesehatan, 15(1), 37-43.

Shayo GA \& Mugusi FM. 2011. Prevalence of obesity and associated risk factors among adults in Kinondoni municipal district, Dar es Salaam Tanzania. BMC Public Health, 11, 365.

Smolin LA \& Grosvenor MB. 2010. Healthy Eating a Guide to Nutrition: Nutrition and Weight Management, Second Edition. New York, Chelsea House Publishing. Swinburn BA, Caterson I, Seidell JC, \& James WPT. 2004. Diet, nutrition and the prevention of excess weight gain and obesity. Public Health Nutrition, 7(1A), 123-146.

Vergnaud A, Norat T, Romaguera D, Mouw T, May AM, Romieu I, Freisling H, Slimani N, Boutron-Ru- 
Diana dkk.

ault M, \& Clavel-Chapelon F et al. 2012. Fruit and vegetable consumption and prospective weight change in participants of the European Prospective Investigation into Cancer and Nutrition-Physical Activity, Nutrition, Alcohol, Cessation of Smoking, Eating Out of Home, and Obesity study. Am J Clin Nutr, 9, 184-93.

Walker LO, Timmerman GM, Sterling BS, Kim M, \& Dickson P. 2004. Do low-income women attain their pre-pregnant weight by the 6th week of postpartum?. Ethn Dis, 14, 119-126.

[WHO] World Health Organization. 2003. WHO Technical Report Series: Diet, Nutrition and the Prevention of Chronic Diseases. WHO, Geneva.

[WHO] World Health Organization. 2010. Global recommendations on physical activity for health.http://whqlidoc. who.int/ publications/2010/9789241599979_eng.pdf [22 Januari 2013]. 